\title{
Metal Levels in Southern Right Whales (Eubalaena australis) from Península Valdés, Argentina
}

\author{
Julieta Martino ${ }^{1,2}$, Sandra S Wise ${ }^{1}$, Christopher Perkins ${ }^{3}$, Mariano Sironi ${ }^{2,4}$ and John Pierce Wise Sr ${ }^{1 *}$
}

${ }^{1}$ Wise Laboratory of Environmental and Genetic Toxicology, Maine Center for Toxicology and Environmental Health, Department of Applied Medical Sciences, University of Southern Maine, 96 Falmouth St., Portland, ME 04104, USA

${ }^{2}$ Instituto de Conservación de Ballenas, CC 39-1623, Buenos Aires, Argentina

${ }^{3}$ Center for Environmental Sciences and Engineering, University of Connecticut, 3107 Horsebarn Hill Road, Building 4 Annex, U-4210 Storrs, CT 06269-4210, USA

${ }^{4}$ Cátedra de Diversidad Animal II, Facultad de Ciencias Exactas, Físicas y Naturales, Universidad Nacional de Córdoba, Av. Vélez Sársfield 299, 5000, Córdoba,

Argentina

\begin{abstract}
Península Valdes, Argentina, is a nursing ground for a population of southern right whales (Eubalaena australis). In the last two decades this area has been subjected to an increase in population, tourism and industrial growth. This has raised the concern for exposure to chemical contaminants such as metals. In this study we measured nonessential metals ( $\mathrm{Ag}, \mathrm{Al}, \mathrm{As}, \mathrm{Au}, \mathrm{Ba}, \mathrm{Be}, \mathrm{Co}, \mathrm{Cd}, \mathrm{Cr}, \mathrm{Hg}, \mathrm{Li}, \mathrm{Ni}, \mathrm{Pb}, \mathrm{Sb}, \mathrm{Sn}, \mathrm{Sr}, \mathrm{U}$ and Ti), essential metals (Cu, $\mathrm{Fe}, \mathrm{Mg}, \mathrm{Mn}, \mathrm{Mo}$ and $\mathrm{Zn}$ ) and an essential element (Se) in skin biopsies from female southern right whales $(n=10)$. This is the first report on tissue concentrations of metals in adult southern right whales. Overall, tissue values were on the low end of the spectrum and similar to the values reported in studies of mysticetes from other regions. Measured values do not reflect substantial amounts of accumulation and thus serve as a baseline.
\end{abstract}

Keywords: Eubalaena australis; Southern right whale; Península Valdés; Metals; Chromium; Aluminum; Barium

\section{Introduction}

The waters around Península Valdes (PV), Argentina, are a nursing ground for a population of southern right whales (Eubalaena australis) $[1,2]$. In the last two decades, and following the trends of other coastal areas of the world, this area has been subjected to an increase in population, tourism and industrial growth. This scenario raises the concern for an increase of contaminants related to these activities and their potential effects on wildlife.

Among contaminants, metals are of particular interest because they are elements and, therefore, cannot be degraded. Thus, they can persist in the environment and be incorporated into organisms, through dermal absorption, inhalation or ingestion, where they accumulate until excreted $[3,4]$. Metals affect multiple cellular and organ functions, including reproduction and development [5,6]. Even essential metals can have deleterious health effects if their concentrations are too high. Specifically, in cetaceans, metal exposure has been correlated with infectious disease mortality, parasitic infections and pneumonias and histopathological changes in lung and kidney tissues [7-9]. Cetacean cell culture studies showed that metals can induce cytotoxic, immunotoxic and genotoxic effects [10-17]. Thus, animal and tissue culture studies suggest that metals could be a health concern to cetaceans.

At Península Valdés, Argentina sources of metals include mining, storage and transport of petroleum, harbor activities and cities that have settled in the area and are expanding [18]. The only aluminum smelter in the country (ALUAR) is located in the city of Puerto Madryn on Golfo Nuevo, the southern gulf of the Peninsula. In addition, sea currents moving in north-south direction bring waters from the Buenos Aires coast which is the most populated and industrialized area of the country with numerous metallurgical, petrochemical, textile and pharmaceutical industries [19]. This suggests that exposure to metals from contaminated water and air is possible for southern right whales that use the PV nursery ground annually from June to December. Moreover, in the last seven years this population has been experiencing high calf mortalities [20-22] and environmental contaminants have been suggested as a contributing factor, among others [23].

Although historically it was thought that baleen whales did not accumulate metals, recent data suggest they can. For example, North Atlantic right whales (Eubalaena glacialis) accumulate high levels of chromium [16]. Currently, the only data regarding metal concentrations in tissues of southern right whales come from dead calves [24,25]. Here we present results from a study in which we collected skin biopsies from live female southern right whales at Península Valdés and analyzed them for metals and selenium. To our knowledge this is the first set of data on metal levels in live individuals from this species and thus, our study serves as a valuable baseline.

\section{Materials and Methods}

\section{Study area and biopsy sampling}

Biopsies were collected from ten adult female southern right whales in San José Gulf, Península Valdés, Argentina (42³0'; S, $64^{\circ}$ 00'; W; Figure 1), during the months of September and October of 2011. Adult females were recognized by the close proximity of a calf over an extended period of time. Animals were approached slowly in a small rubber boat. Prior to biopsying, the callosity patterns on the head of each whale were photographed to avoid resampling the same individual [26]. Whales were biopsied on their flanks using a crossbow and a dart, following standard methods described in Brown et al. [27]

*Corresponding author: John Pierce Wise Sr., University of Southern Maine, 478 Science Building, 96 Falmouth Street, Portland, ME 04103, Tel: 1-207-228-8050; Fax: 1-207-228-8518; E-mail: John.Wise@usm.maine.edu

Received August 02, 2013; Accepted September 15, 2013; Published September 18, 2013

Citation: Martino J, Wise SS, Perkins C, Sironi M, Wise JP Sr (2013) Metal Levels in Southern Right Whales (Eubalaena australis) from Península Valdés, Argentina. J Environ Anal Toxicol 3: 190. doi:10.4172/2161-0525.1000190

Copyright: ( 2013 Martino J, et al. This is an open-access article distributed under the terms of the Creative Commons Attribution License, which permits unrestricted use, distribution, and reproduction in any medium, provided the original author and source are credited. 


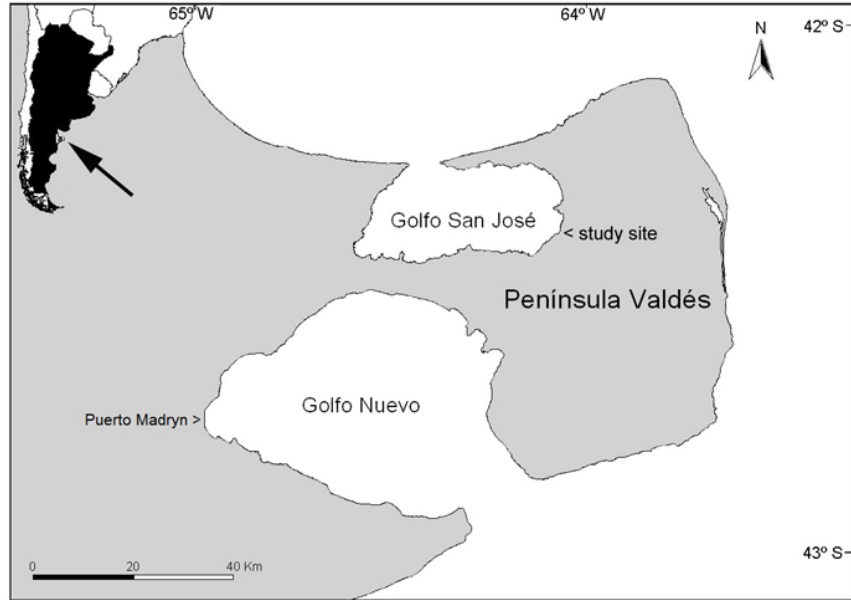

Figure 1: Map of Península Valdés, Argentina showing the San José Gulf, and the study site where the samples were collected, as well as the nearby city of Puerto Madryn, located on Golfo Nuevo. Inset shows the position of Península Valdés on the South American coast.

A $60 \mathrm{~mm} \times 6 \mathrm{~mm}$ stainless steel cylindrical biopsy dart was used. All tissue samples were immediately frozen after collection, stored in a liquid nitrogen dewar and shipped frozen to the laboratory.

\section{Metal analysis}

Whale skin samples were analyzed for total levels of antimony $(\mathrm{Sb})$, arsenic (As), barium (Ba), beryllium $(\mathrm{Be})$, cadmium $(\mathrm{Cd})$, chromium $(\mathrm{Cr})$, cobalt $(\mathrm{Co})$, copper $(\mathrm{Cu})$, gold $(\mathrm{Au})$, lead $(\mathrm{Pb})$, lithium $(\mathrm{Li})$, manganese (Mn), molybdenum (Mo), nickel (Ni), selenium (Se), silver $(\mathrm{Ag})$, strontium $(\mathrm{Sr})$, tin $(\mathrm{Sn})$, titanium $(\mathrm{Ti})$, uranium $(\mathrm{U})$ and zinc (Zn) using a Perkin-Elmer/Sciex ELAN inductively coupled plasmamass spectrometer (ICP-MS) according to EPA Method 6020A [28]. Aluminum ( $\mathrm{Al})$, iron $(\mathrm{Fe})$, and magnesium $(\mathrm{Mg})$ were measured using inductively coupled plasma-optical emission spectrometry (ICP-OES) according to EPA Method 6010B [29]. Mercury (Hg) was analyzed by thermal decomposition atomic absorbance using a Milestone DMA-80 according to EPA Method 7473 [30].

For analysis by ICP and ICP-MS, samples were rinsed with deionized water and allowed to air dry in a laminar flow hood to minimize contamination. Approximately $0.1 \mathrm{~g}$ of tissue was placed in a digestion vessel, $2 \mathrm{ml}$ of Optima grade nitric acid (Fisher Scientific, Pittsburg, PA) was added, the vessel placed in a hot block, and refluxed at $95^{\circ} \mathrm{C}$ for 4 hours. The sample was cooled, $2 \mathrm{ml}$ Optima grade hydrogen peroxide (Fisher Scientific, Pittsburg, PA) and deionized water $(3: 2 \mathrm{v} / \mathrm{v})$ was added, heated until the effervescence subsided, cooled, and brought up to a final volume of $20 \mathrm{ml}$.

Standard quality assurance procedures were employed (Table 1) and include the analysis of standard reference materials, a duplicate sample and a pre-digestion spike. Instrument response was evaluated initially and after the 10 samples, using commercially available calibration verification standards (Claritas PPT multi-element solution 2 - Spex CertiPrep, Metuchen, NJ; individual elemental standards-SCP Science, Baie-D'Urfe, Quebec, Canada) and a blank. All calibration verifications $(n=5)$ were within the acceptance criterion of $85-115 \%$ recovery and the all preparation blank values were below $3 \mathrm{x}$ the limit of detection. Standard reference materials (DOLT-4 and DORM-3NIST, Charleston, SC) were used to assess method performance, where applicable. Interference check solutions (ICS A and ICS A+B- High Purity Standards, Charleston, SC) were analyzed with all sample runs to check for matrix effects which might be interfering with sample analysis.

The mean limit of detection (LOD) and project quantitation limit (PQL) values are presented in Table 1 , since there is slight variability between samples due to differences in sample mass. The LOD was the lowest analyte concentration likely to be reliably distinguished from the blank and at which detection is feasible. The LOD was previously determined by utilizing both the measured blank and test replicates of a matrix matched sample known to contain a low concentration of analyte. Additionally, a series of PQL samples was run for each element to assess low level analytical performance, with an acceptance criterion of $50-150 \%$. All samples were diluted $2 \mathrm{x}$ for analysis by ICP-MS.

Tissue concentrations are reported in $\mu \mathrm{g} / \mathrm{g}$ per wet weight of tissue $(\mu \mathrm{g} / \mathrm{g} w w)$. Some concentrations in the literature are reported as per dry weight of tissue and do not include information on water content. Hence, in order to roughly compare our data with those studies, we transformed literature values to per wet weight values by multiplying them by a factor of 0.25 , which corresponds to a typical dry/wet weight ratio of most tissues [31].

\section{Results}

Average tissue concentrations $(\mu \mathrm{g} / \mathrm{g} w \mathrm{w})$ for each element are summarized in Tables 2 and 3 and are expressed as the mean \pm standard deviation of the mean. The minimum and maximum values measured are also indicated. When calculating the mean of each element, values that were reported as non-detectable were replaced by $1 / 2$ the limit of detection value for that given element. Among nonessential metals, $\mathrm{Al}$ had the highest value with an average of $9.75 \pm 2.7 \mu \mathrm{g} / \mathrm{g}$ tissue $(\mathrm{w} / \mathrm{w})$. $\mathrm{U}$ and Co were not detected in any of the samples. The remaining nonessential metals measured ( $\mathrm{Au}, \mathrm{Sn}, \mathrm{Cd}, \mathrm{Li}, \mathrm{Sb}, \mathrm{Ag}, \mathrm{Be}, \mathrm{Hg}, \mathrm{As}, \mathrm{Pb}, \mathrm{Ni}$, $\mathrm{Ba}, \mathrm{Cr}, \mathrm{Sr}$ and $\mathrm{Ti}$ ) had averages that ranged from 0.11 to $3.95 \mu \mathrm{g} / \mathrm{g}$ tissue $(w / w)$. Nonessential metal values in decreasing order of concentration are: $\mathrm{Al}>\mathrm{Ti}>\mathrm{Sr}>\mathrm{Cr}>\mathrm{Ba}>\mathrm{Ni}>\mathrm{Pb}>\mathrm{As}>\mathrm{Au}>\mathrm{Sn}>\mathrm{Cd}, \mathrm{Li}, \mathrm{Sb}>\mathrm{Ag}>\mathrm{Be}, \mathrm{Hg}$. Within the essential metals/element (i.e. selenium), $\mathrm{Mg}$ had the highest value with an average of $187.02 \pm 9.1 \mu \mathrm{g} / \mathrm{g}$ tissue $(\mathrm{w} / \mathrm{w})$. Average tissue levels of $\mathrm{Mo}, \mathrm{Mn}, \mathrm{Cu}, \mathrm{Se}, \mathrm{Fe}$ and $\mathrm{Zn}$ ranged from 0.02 to $14.71 \mu \mathrm{g} / \mathrm{g}$ tissue $(\mathrm{w} / \mathrm{w})$.

\section{Discussion}

Our study is the first to report metal concentrations in southern right whale skin from live adult animals. Overall, metal concentrations were generally low. Two previous studies investigated metals in southern right whales calves found dead on the beach in PV. One study reported metals in liver, kidney and muscle of a single calf [24]. The second study reported liver and kidney levels in 45 dead calves [25]. Table 4 shows a comparison between our findings and those of the previous studies. Overall, we found $\mathrm{Al}, \mathrm{Cd}, \mathrm{Hg}, \mathrm{Ni}$ and $\mathrm{Pb}$ concentrations similar to those in the dead calves, but lower $\mathrm{Cu}, \mathrm{Fe}$, $\mathrm{Mn}$ and $\mathrm{Zn}$ concentrations.

These lower concentrations could be due to differences in the specific tissues evaluated. We measured skin, while previous studies focused on liver, kidney and muscle. Metals are known to preferentially accumulate in these internal organs more than the skin [32]. In minke whales (Balaenoptera acutorostrata), $\mathrm{Cr}$ and Cd skin levels correlate with those found in the liver [33] suggesting that skin levels could potentially reflect levels of internal organs. However, in a study in bowhead whales (Balaena mysticetus) [34] that compared 
Citation: Martino J, Wise SS, Perkins C, Sironi M, Wise JP Sr (2013) Metal Levels in Southern Right Whales (Eubalaena australis) from Península Valdés, Argentina. J Environ Anal Toxicol 3: 190. doi:10.4172/2161-0525.1000190

Page 3 of 6

\begin{tabular}{|c|c|c|c|c|c|c|c|}
\hline Element & LOD $^{a}$ & $P Q L^{b}$ & $\begin{array}{l}\text { Calibration Blank }{ }^{c} \\
n=5\end{array}$ & $\begin{array}{l}\text { Duplicate (RPD) (\%) } \\
n=1\end{array}$ & $\begin{array}{l}\text { LCS Recovery }(\%) \\
n=1\end{array}$ & $\begin{array}{l}\text { Spike Recovery (\%) } \\
n=1\end{array}$ & $\begin{array}{l}\text { SRMd Recovery (\%) DORM-3/ } \\
\text { DOLT-4 n=1 }\end{array}$ \\
\hline Aluminum (Al) & 2.3 & 18.0 & $\mathrm{ND}^{\mathrm{e}}$ & 3.6 & 95.1 & 98.3 & 87.3 \\
\hline Antimony (Sb) & 0.05 & 0.18 & ND & BDL & 103.4 & 109.9 & N/A \\
\hline Arsenic (As) & 0.09 & 0.18 & ND & BDL & 97.9 & 107.6 & 99.8 \\
\hline Barium (Ba) & 0.09 & 0.18 & ND & 5.9 & 98.1 & 104.9 & $N / A$ \\
\hline Beryllium (Be) & 0.02 & 0.19 & ND & BDL & 108.3 & 105.6 & N/A \\
\hline Cadmium (Cd) & 0.02 & 0.18 & ND & BDL & 94.4 & 101.3 & 102.5 \\
\hline Chromium (Cr) & 0.18 & 0.46 & ND & 8.9 & 107.8 & 94.7 & 116.7 \\
\hline Cobalt (Co) & 0.02 & 0.18 & ND & BDL & 97.1 & 98.8 & N/A \\
\hline Copper (Cu) & 0.05 & 0.18 & ND & 13.8 & 93.7 & 97.4 & 86.6 \\
\hline Gold (Au) & 0.09 & 0.18 & ND & BDL & 95.9 & 96.8 & N/A \\
\hline Iron $(\mathrm{Fe})$ & 2.30 & 18.0 & ND & 1.5 & 92.0 & 95.6 & 92.5 \\
\hline Lead $(\mathrm{Pb})$ & 0.05 & 0.18 & ND & 4.2 & 93.3 & 97.3 & 107.9 \\
\hline Lithium (Li) & 0.05 & 0.18 & ND & BDL & 106.2 & 106.1 & N/A \\
\hline Magnesium (Mg) & 2.30 & 18.0 & ND & 9.6 & 96.4 & 97.4 & N/A \\
\hline Manganese (Mn) & 0.02 & 0.18 & ND & 18.7 & 104.6 & 106.0 & 80.9 \\
\hline Mercury (Hg) & 0.02 & 0.02 & ND & 99.4 & 96.7 & 105.1 & 98.8 \\
\hline Molybdenum (Mo) & 0.02 & 0.18 & ND & BDL & 105.4 & 108.5 & N/A \\
\hline Nickel (Ni) & 0.05 & 0.18 & ND & 19.6 & 95.2 & 95.8 & 88.3 \\
\hline Selenium (Se) & 0.05 & 0.18 & ND & 1.9 & 101.4 & 104.4 & 103.2 \\
\hline Silver (Ag) & 0.02 & 0.18 & ND & BDL & 107.2 & 110.7 & 92.9 \\
\hline Strontium (Sr) & 0.02 & 0.18 & ND & 1.5 & 104.0 & 112.4 & N/A \\
\hline Tin (Sn) & 0.05 & 0.18 & ND & 13.6 & 110.0 & 115.0 & N/A \\
\hline Titanium (Ti) & 0.05 & 0.18 & ND & 17.9 & 112.1 & 110.3 & N/A \\
\hline Uranium (U) & 0.02 & 0.18 & ND & BDL & 103.1 & 105.9 & N/A \\
\hline Zinc (Zn) & 0.18 & 0.92 & ND & 13.9 & 97.2 & 107.7 & 98.2 \\
\hline
\end{tabular}

a LOD = limit of detection (ppm, mean)

${ }^{\mathrm{b}} \mathrm{PQL}=$ project quantitation limit (ppm, mean)

c Calibration blank: ppm, mean

${ }^{\mathrm{d}} \mathrm{SRM}=$ standard reference material

e ND = not detected

Table 1: Quality assurance and quality control data for element analysis.

\begin{tabular}{|c|c|c|c|c|c|c|c|}
\hline Element & \begin{tabular}{|l|} 
Mean \\
Range
\end{tabular} & $n(n d)^{a}$ & $\begin{array}{l}\text { Detection } \\
\text { Limit }^{\mathrm{b}}\end{array}$ & Element & $\begin{array}{l}\text { Mean } \\
\text { Range }\end{array}$ & $n(n d)^{a}$ & $\begin{array}{l}\text { Detection } \\
\text { Limit }^{\mathrm{b}}\end{array}$ \\
\hline Al & $\begin{array}{l}9.75 \pm 2.7 \\
3.1-24.8\end{array}$ & $10(9)$ & 2.3 & Sn & $\begin{array}{l}0.07 \pm 0 \\
0.06-0.18\end{array}$ & $10(7)$ & 0.05 \\
\hline $\mathrm{Ti}$ & $\begin{array}{l}3.95 \pm 0.2 \\
3.5-5.72\end{array}$ & $10(10)$ & 0.05 & Cd & $\begin{array}{l}0.04 \pm 0 \\
0.03-0.21\end{array}$ & $10(6)$ & 0.02 \\
\hline $\mathrm{Sr}$ & $\begin{array}{l}0.87 \pm 0.1 \\
0.54-1.46\end{array}$ & $10(10)$ & 0.02 & $\mathrm{Li}$ & $\begin{array}{l}0.04 \pm 0 \\
0.05-0.08\end{array}$ & $10(3)$ & 0.05 \\
\hline $\mathrm{Cr}$ & $\begin{array}{l}0.64 \pm 0.2 \\
0.19-2.15\end{array}$ & $10(9)$ & 0.18 & Sb & $\begin{array}{l}0.04 \pm 0 \\
0.07-0.08\end{array}$ & $10(2)$ & 0.05 \\
\hline $\mathrm{Ba}$ & $\begin{array}{l}0.32 \pm 0.1 \\
0.1-1.08\end{array}$ & $10(9)$ & 0.09 & Ag & $\begin{array}{l}0.02 \pm 0 \\
0.06\end{array}$ & $10(1)$ & 0.02 \\
\hline $\mathrm{Ni}$ & $\begin{array}{l}0.19 \pm 0 \\
0.06-0.51\end{array}$ & $10(10)$ & 0.05 & $\mathrm{Hg}$ & $\begin{array}{l}0.01 \pm 0 \\
0.02-0.03\end{array}$ & $10(2)$ & 0.02 \\
\hline $\mathrm{Pb}$ & $\begin{array}{l}0.15 \pm 0 \\
0.08-0.53\end{array}$ & $10(8)$ & 0.05 & $\mathrm{Be}$ & $\begin{array}{l}0.0 .1 \pm 0 \\
0.03\end{array}$ & $10(1)$ & 0.02 \\
\hline As & $\begin{array}{l}0.11 \pm 0 \\
0.19-0.41\end{array}$ & $10(3)$ & 0.09 & $\mathbf{U}$ & $N^{c}$ & $10(0)$ & 0.02 \\
\hline $\mathrm{Au}$ & $\begin{array}{l}0.09 \pm 0 \\
0.23-0.33\end{array}$ & $10(2)$ & 0.09 & Co & $N^{c}$ & $10(0)$ & 0.02 \\
\hline
\end{tabular}

${ }^{a} \mathrm{n}(\mathrm{nd})=$ Total number of samples (Number of samples with detectable levels)

${ }^{b}$ Detection limit $=\mu \mathrm{g} / \mathrm{g}$

${ }^{\mathrm{c}} \mathrm{ND}=$ Not detected

Table 2: Concentrations $(\mu \mathrm{g} / \mathrm{g} \mathrm{ww})$ of nonessential metals in skin biopsies from ten adult female southern right whales. Data represent the mean \pm standard deviation of the mean and the range of minimum-maximum values measured. 
Citation: Martino J, Wise SS, Perkins C, Sironi M, Wise JP Sr (2013) Metal Levels in Southern Right Whales (Eubalaena australis) from Península Valdés, Argentina. J Environ Anal Toxicol 3: 190. doi:10.4172/2161-0525.1000190

Page 4 of 6

\begin{tabular}{|c|c|c|c|c|c|c|c|}
\hline Element & $\begin{array}{l}\text { Mean } \\
\text { Range }\end{array}$ & $n(n d)^{a}$ & $\begin{array}{l}\text { Detection } \\
\text { Limit }^{\mathrm{b}}\end{array}$ & Element & $\begin{array}{l}\text { Mean } \\
\text { Range }\end{array}$ & $n(n d)^{a}$ & $\begin{array}{l}\text { Detection } \\
\text { Limit }^{\mathrm{b}}\end{array}$ \\
\hline Mg & $\begin{array}{l}187.02 \pm 9.1 \\
138.1-230.8\end{array}$ & $10(10)$ & 2.3 & $\mathrm{Cu}$ & $\begin{array}{l}0.35 \pm 0.1 \\
0.09-0.67\end{array}$ & $10(10)$ & 0.05 \\
\hline$Z n$ & $\begin{array}{l}14.71 \pm 0.6 \\
12.79-19.67\end{array}$ & $10(10)$ & 0.18 & Mn & $\begin{array}{l}0.27 \pm 0.1 \\
0.1-0.74\end{array}$ & $10(10)$ & 0.02 \\
\hline $\mathrm{Fe}$ & $\begin{array}{l}7.24 \pm 3 \\
2.3-32.3\end{array}$ & $10(7)$ & 2.3 & Mo & $\begin{array}{l}0.02 \pm 0 \\
0.02-0.06\end{array}$ & $10(6)$ & 0.02 \\
\hline Se & $\begin{array}{l}2.06 \pm 0.4 \\
0.7-4.4\end{array}$ & $10(10)$ & 0.05 & & & & \\
\hline
\end{tabular}

${ }^{a} \mathrm{n}(\mathrm{nd})=$ Total number of samples (Number of samples with detectable levels)

${ }^{b}$ Detection limit $=\mu \mathrm{g} / \mathrm{g}$

Table 3: Concentrations ( $\mu \mathrm{g} / \mathrm{g} \mathrm{ww}$ ) of essential metals and one essential element (Se) in skin biopsies from ten adult female southern right whales. Data represent the mean \pm standard deviation of the mean and the range of minimum-maximum values measured.

\begin{tabular}{|c|c|c|c|c|c|c|}
\hline \multirow{2}{*}{$\begin{array}{l}\text { Studies } \\
\text { Metal/Organ }\end{array}$} & \multirow{2}{*}{$\begin{array}{l}\text { This Study } \\
\mathrm{n}=10 \\
\text { Adult Females } \\
\text { Skin } \\
\end{array}$} & \multicolumn{3}{|c|}{$\begin{array}{l}\text { Gil et al. (2006) } \\
n=1 \\
\text { Calf }\end{array}$} & \multicolumn{2}{|c|}{$\begin{array}{l}\text { Rosas et al. (2012) } \\
n=45 \\
\text { Calves }\end{array}$} \\
\hline & & Liver & Kidney & Muscle & Liver & Kidney \\
\hline Al & 3.1-24.8 & $\mathrm{NM}^{\mathrm{b}}$ & $\mathrm{NM}^{\mathrm{b}}$ & $\mathrm{NM}^{\mathrm{b}}$ & $1.0-26.5$ & $1.1-22.7$ \\
\hline Cd & $0.03-0.21$ & 0.04 & 0.04 & 0.04 & $N^{a}$ & $N^{a}$ \\
\hline $\mathrm{Cu}$ & $0.09-0.67$ & 18.6 & 5.7 & 2.6 & $1.88-264.41$ & $1.67-5.65$ \\
\hline $\mathrm{Fe}$ & $2.3-32.3$ & $\mathrm{NM}^{\mathrm{b}}$ & $\mathrm{NM}^{\mathrm{b}}$ & $\mathrm{NM}^{\mathrm{b}}$ & $25.5-184.48$ & 16.1-120.6 \\
\hline $\mathrm{Hg}$ & $0.02-0.03$ & $N D^{a}$ & 0.04 & 0.04 & $\mathrm{NM}^{\mathrm{b}}$ & $\mathrm{NM}^{\mathrm{b}}$ \\
\hline Mn & $0.1-0.74$ & $N^{b}$ & $\mathrm{NM}^{\mathrm{b}}$ & $N M^{b}$ & $0.09-2.9$ & $0.15-3.33$ \\
\hline $\mathrm{Ni}$ & $0.06-0.51$ & $N^{b}$ & $N^{b}$ & $N M^{b}$ & $0.13-0.22$ & $0.1-0.94$ \\
\hline $\mathrm{Pb}$ & $0.08-0.53$ & 0.13 & 0.12 & 0.13 & $N D^{a}$ & $N D^{a}$ \\
\hline $\mathrm{Zn}$ & 12.79-19.67 & $\mathrm{NM}^{\mathrm{b}}$ & 54 & 83 & $0.23-303.01$ & $11.42-45.67$ \\
\hline
\end{tabular}

${ }^{\mathrm{a}} \mathrm{ND}=$ not detected

${ }^{\mathrm{b}} \mathrm{NM}=$ not measured

Table 4: Summary of reported metal concentrations $(\mu \mathrm{g} / \mathrm{g} \mathrm{ww})$ in tissues of southern right whales. These concentrations reflect the minimum and maximum values measured in each study.

concentrations of essential and nonessential elements in skin biopsies versus muscle, liver, blubber and kidney, skin values were not able to predict or correlate with the values measured in internal organs. In the case of southern right whales, there are no data available on metal concentrations in internal organs from adult whales to determine whether such a correlation exists or not. More data is needed to answer this important toxicological question.

Aluminum (Al) levels were of particular interest because of the presence of an $\mathrm{Al}$ smelter in the nearby city of Puerto Madryn, located on Golfo Nuevo, the southern Gulf of PV (Figure 1). Nine out of ten animals had detectable levels of Al. The levels found were comparable to those measured in liver and kidney of dead calves from PV [25]. Lower or similar levels of $\mathrm{Al}$ to those measured in our study were also found in liver, kidney and brain of juvenile gray whales (Eschrichtius robustus) from a subsistence harvest [35]. However, they were higher than those reported in livers of bowhead whales [36]. Taking into account that these studies measured $\mathrm{Al}$ in different tissues and hence direct comparisons are not possible, the $\mathrm{Al}$ concentrations we found appear to be low. These data would suggest that southern right whales are not experiencing higher exposure to $\mathrm{Al}$ as a result of the nearby smelter.

Previously we investigated Cr levels in skin biopsies from North Atlantic right whales [16], a species closely related to southern right whales. The average Cr levels in North Atlantic right whales were approximately ten times higher $(7.1 \mu \mathrm{g} / \mathrm{g} \mathrm{ww})$ than those we found in southern right whales $(0.64 \mu \mathrm{g} / \mathrm{g} w \mathrm{w})$. Similar protocols were used in each study. The explanation for this difference is uncertain, but is likely due to the fact that North Atlantic right whales live along one of the most industrialized coasts in the world while there is no significant chromium industry around PV.

Only a few studies have reported metal levels from skin biopsies of other baleen whales. De Luna and Rosales-Hoz [37] measured As, $\mathrm{Fe}, \mathrm{Mn}, \mathrm{Pb}, \mathrm{Se}$ and $\mathrm{Zn}$ in skin of calf, juvenile and adult gray whales at Ojo de Liebre Lagoon, Mexico. Levels of As were similar to those in our study but the $\mathrm{Pb}$ level they report for adult gray whales is much higher than our study $(\sim 3.75 \mu \mathrm{g} / \mathrm{g}$ ww vs. $0.15 \mu \mathrm{g} / \mathrm{g} w w)$. This could be explained by differences in feeding behavior between gray and southern right whales. Gray whales are benthic bottom feeders that filter sediments in order to obtain their prey [38]. Higher levels of $\mathrm{Pb}$ could be due to a higher exposure resulting from the ingestion of sediments, which contain metals from natural or anthropogenic sources. Fe, Mn, Se and Zn levels in our study were higher than the levels found in these gray whales. This difference could be due to a low sample number $(\mathrm{n}=3)$ in the De Luna and Rosales-Hoz [37] study but could also reflect differences among sampling sites, ingested prey or species-specific differences in the toxicokinetics of these elements.

$\mathrm{Ba}, \mathrm{Cu}, \mathrm{Cd}, \mathrm{Cr}, \mathrm{Mn}, \mathrm{Hg}$, Sr, Se and $\mathrm{Zn}$ were measured in skin of 39 female minke whales in the southern hemisphere [33]. Our data are consistent with their $\mathrm{Cu}, \mathrm{Cr}, \mathrm{Hg}$, Sr and $\mathrm{Zn}$ concentrations but different for $\mathrm{Ba}, \mathrm{Cd}, \mathrm{Mn}$ and $\mathrm{Se}$. The biggest difference is with $\mathrm{Ba}$, which was almost ninety-fold higher in our study $(0.004 \mu \mathrm{g} / \mathrm{g}$ ww vs. $0.35 \mu \mathrm{g} / \mathrm{g}$ ww). Barium sulfate is widely used to make drilling fluids used in oil and gas extractions [39], an activity that is very prevalent in the Patagonia region surrounding PV. The higher levels of $\mathrm{Ba}$ in southern right whale might reflect a higher exposure to these Ba-containing compounds. However, barium sulfate is insoluble in water. An interesting, albeit 
Citation: Martino J, Wise SS, Perkins C, Sironi M, Wise JP Sr (2013) Metal Levels in Southern Right Whales (Eubalaena australis) from Península Valdés, Argentina. J Environ Anal Toxicol 3: 190. doi:10.4172/2161-0525.1000190

untested, possibility is that right whales could be ingesting undissolved barium particles from the water column. Studies in rats suggest that once in the digestive tract, insoluble barium compounds could be slowly absorbed [40]. Mn was thirteen times higher in our study $(0.02$ $\mu \mathrm{g} / \mathrm{g}$ ww vs. $0.27 \mu \mathrm{g} / \mathrm{g} w w)$ and Se was almost four-fold higher in their study $(7.75 \mu \mathrm{g} / \mathrm{g}$ ww vs. $2.06 \mu \mathrm{g} / \mathrm{g} w w)$. Mn and Se are essential elements and thus, their absorption and excretion are tightly regulated. As mentioned earlier, these differences could be attributed to speciesspecific differences. Even though Cd was ten times higher in our study $(0.004 \mu \mathrm{g} / \mathrm{g}$ ww vs. $0.04 \mu \mathrm{g} / \mathrm{g} \mathrm{ww})$ these values are still considered low.

In summary, this is the first study to report metal concentrations in live southern right whales. Overall, our data suggest that metal concentrations in southern right whales from PV are low and thus, could provide a valuable baseline for metals in skin tissue of this species. These low concentrations should not necessarily be interpreted as being safe since the effects of metals in marine mammals are largely unknown. Future work is aimed at providing more data from live southern right whales, including females, males as well as other age classes and reproductive status.

\section{Acknowledgments}

We would like to thank Diego Taboada, Roxana Schteinbarg, Carina Marón, Marcos Ricciardi, Florencia Vilches, Dr. Luciano Valenzuela, lain Kerr, Kim Marshall-Tilas, Carolyne LaCerte and volunteers from Instituto de Conservación de Ballenas/Ocean Alliance for their help with logistics, fieldwork, permits, and preparation of samples. We thank Victoria Rowntree for reading the manuscript and for her valuable suggestions and comments. We thank the Southern Right Whale Health Monitoring Program, especially Marcela Uhart and Matías Di Martino, and Hotel ACA-Puerto Pirámides for providing logistical support. We also thank the Armada Argentina and Guillermo Harris from Wildlife Conservation Society and Fundación Patagonia Natural for permission to use the research station. We thank Moira Brown for providing the crossbow used for biopsying, and Virginia Roldán for creating the map of Península Valdés in Figure 1. We thank Christy Gianios, $\mathrm{Jr}$, and Shou-Ping Huang for information technology and administrative support.

Biopsy collection was conducted under permits from the Chubut Province: Dirección de Fauna y Flora Silvestre (DFyFS), DFyFS-SSRN-N ${ }^{\circ} 89 / 2011$, and Secretaría de Turismo y Areas Protegidas (SSTyAP) del Organismo Provincial de Turismo (OPT), SSTyAP-N¹93/2011. Export of biopsies was done under Argentine permits from the Secretaría de Ambiente y Desarrollo Sustentable (SAyDS): Certificado Biodiversidad N³1527, Certificado Fauna №31535, CITES N ${ }^{\circ} 35575 / 35576$ and from the Servicio Nacional de Sanidad y Calidad Agroalimentaria (SENASA): Certificado Sanitario $N^{\circ} 04329 U B$. Biopsy samples were imported to USA under NMFS permits \#13545 and \#1008-1637-00 and CITES permit \#11US819824/9. Work conducted in the Wise Laboratory was done under NMFS permit \#1008-1637-00 (J. Wise Sr., PI)

This work was funded by NIEHS grant ES016893 (JPW), the Maine Cente for Toxicology and Environmental Health (JPW), the Southern Right Whale Program (ICB/WCI-OA), a Fulbright Scholarship (JM) and a Delta Kappa Gamma International Fellowship (JM). The content is solely the responsibility of the authors and does not necessarily represent the official views of the National Institute of Environmental Health Sciences or the National Institutes of Health.

\section{References}

1. Payne R (1986) Long term behavioral studies of the southern right whale (Eubalaena australis). Report of the International Whaling Commission Special Issue 10: 161-167.

2. Payne R, Rowntree V, Perkins JS, Cooke JG, Lankester K (1990) Population size, trends and reproductive parameters of right whales (Eubalaena australis) off Peninsula Valdes, Argentina. Report of the International Whaling Commission Special Issue 12: 271-278.

3. Beckett WS, Nordberg GF, Clarkson TW (2007) Routes of exposure, dose and metabolism of metals: Handbook on the Toxicology of Metals. (3rdedn), Academic Press, Burlington, Massachusetts.

4. Liu J, Goyer RA, Waalkes MP (2008): Toxic Effects of Metals: Casarett \& Doull's Toxicology: The Basic Science of Poisons. (7thedn), McGraw Hill, New York.

5. Apostoli P, Telisman S, Sager PR (2007) Reproductive and developmenta toxicity of metals: Handbook on the Toxicology of Metals. (3rdedn), Academic Press, Burlington, Massachusetts.

6. Foster PMD, Gray Jr LE (2008) Toxic responses of the reproductive system Casarett \& Doull's Toxicology: The Basic Science of Poisons. (7thedn), McGraw Hill, New York, USA.

7. Siebert U, Joiris C, Holsbeek L, Benkes H, Failing K, et al. (1999) Potential relation between mercury concentrations and necropsy findings in cetaceans from sGerman waters of the North and Baltic Seas. Mar Pollut Bull 38: 285-295.

8. Bennett PM, Jepson PD, Law RJ, Jones BR, Kuiken T, et al. (2001) Exposure to heavy metals and infectious disease mortality in harbour porpoises from England and Wales. Environ Pollut 112: 33-40.

9. Rosa C, Blake JE, Bratton GR, Dehn LA, Gray MJ, et al. (2008) Heavy metal and mineral concentrations and their relationship to histopathological findings in the bowhead whale (Balaena mysticetus). Sci Total Environ 399: 165-278.

10. Betti C, Nigro M (1996) The comet assay for the evaluation of the genetic hazard of pollutants in cetaceans: Preliminary results on the genotoxic effects of methyl-mercury on the bottle-nosed dolphin (Tursiops truncatus) lymphocytes in vitro. Mar Pollut Bull 32: 545-548.

11. De Guise S, Bernier J, Martineau D, Béland P, Fournier M (1996) Effects of in vitro exposure of beluga whale splenocytes and thymocytes to heavy metals. Environ Toxicol Chem 15: 1357-1364.

12. Gauthier JM, Dubeau H, Rassart E (1998) Mercury-induced micronuclei in skin fibroblast of beluga whales. Environ Toxicol Chem 17: 2487-2493.

13. Cámara Pellissó S, Muñoz MJ, Carballo M, Sánchez-Vizcaíno JM (2008) Determination of the inmunotoxic potential of heavy metals on the functional activity of bottlenose dolphin leukocytes in vitro. Vet Immunol Immunop 121 189-198.

14. Particulate hexavalent chromium is cytotoxic and genotoxic to the North Atlantic right whale (Eubalaena glacialis) lung and skin fibroblasts

15. Comparative cytotoxicity and genotoxicity of particulate and soluble hexavalent chromium in human and sperm whale (Physeter macrocephalus) skin cells

16. Wise JP, Wise SS, Kraus S, Shaffiey F, Grau M, et al. (2008) Hexavalent chromium is cytotoxic and genotoxic to the North Atlantic right whale (Eubalaena glacialis) lung and testes fibroblasts. Mutat Res 650: 30-38.

17. Wise Sr JP, Wise SS, LaCerte C, Wise Jr JP, Aboueissa AM (2011) The genotoxicity of particulate and soluble chromate in sperm whale (Physeter macrocephalus) skin fibroblasts. Environ Mol Mutagen 52: 43-49.

18. Marcovecchio JE, Gerpe MS, Bastida RO, Rodriguez DH, Moron SG (1994) Environmental contamination and marine mammals in coastal waters from Argentina: an overview. Sci Total Environ 154: 141-151.

19. Bisbal GA (1995) The Southeast South American shelf large marine ecosystem. Mar Policy 19: 21-38.

20. Uhart M, Rowntree VJ, Sironi M, Chirife A, Mohamed N, et al. (2009) Continuing southern right whale mortality events at Península Valdés, Argentina. Pape SC/61/BRG18 presented to the International Whaling Commission Scientific Committee.

21. Rowntree V, Uhart M, Sironi M, Chirife A, La Sala L, et al. (2011) Mortalities of right whales (Eubalaena australis) at Península Valdés between 1971 and 2010: recent increases and their possible causes. Paper SC/S11/RW2 presented to the International Whaling Commission.

22. Sironi M, Rowntree VJ, Di Martino M, Chirife A, Bandieri L, et al. (2012 Southern right whale mortalities at Península Valdés, Argentina: updated information for 2010-2011. Paper SC/64/BRG12 presented to the International Whaling Commission Scientific Committee.

23. International Whaling Commission (2010) Report of the southern right whale die-off workshop. J Cetacean Res Manage Supplement 12: 367-398.

24. Gil MN, Torres A, Harvey M, Esteves JL (2006) Metales pesados en organismos marinos de la zona costera de la Patagonia Argentina continental. Rev Biol Mar Oceanog 41: 167-176.

25. Rosas CL, Gil MN, Uhart MM (2012) Trace metal concentrations in southern right whale (Eubalaena australis) at Península Valdés, Argentina. Mar Pollut Bull 64: 1255-1260.

26. Payne R, Brazier O, Dorsey EM, Perkins JS, Rowntree VJ, et al. (1983) 
Citation: Martino J, Wise SS, Perkins C, Sironi M, Wise JP Sr (2013) Metal Levels in Southern Right Whales (Eubalaena australis) from Península Valdés, Argentina. J Environ Anal Toxicol 3: 190. doi:10.4172/2161-0525.1000190

External features in southern right whales, Eubalaena australis, and their use in identifying individuals: Communication and Behavior of Whales. (1stedn), AAAS Selected Symposium, Westview Press Inc, Boulder, Colorado.

27. Brown MW, Kraus SD, Gaskin DE (1991) Reaction of North Atlantic right whales (Eubalaena glacialis) to skin biopsy sampling for genetic and pollutant analysis. Report of the International Whaling Commission Special Issue 13: 81-90.

28. Environmental Protection Agency (2007) Inductively coupled plasma-mass spectrometry: Method 6020A. EPA, Washington D.C, USA.

29. Environmental Protection Agency (1996) Inductively coupled plasma-atomic emission spectrometry: Method 6010B. EPA, Washington D.C, USA.

30. Environmental Protection Agency (2007) Mercury in solids and solutions by thermal decomposition, amalgamation, and atomic absorption spectrophotometry: Method 7473. EPA, Washington D.C.

31. Yang J, Miyazaki N (2003) Moisture content in Dall's porpoise (Phocoenoides dalli) tissues: a reference base for conversion factors between dry and wet weight trace element concentrations in cetaceans. Environ Pollut 121: 345-347.

32. Law RJ (1996) Metals in marine mammals: Environmental Contaminants in Wildlife: Interpreting Tissue Concentrations. (1stedn), SETAC Special Publications Series, CRC Press Inc, Lewis Publishers Inc, Boca Raton, Florida.

33. Kunito T, Watanabe I, Yasunaga G, Fujise Y, Tanabe S (2002) Using trace elements in skin to discriminate the populations of minke whales in southern hemisphere. Mar Environ Res 53: 175-197.

34. O'Hara TM, Hanns C, Woshner VM, Zeh J, Bratton G, et al. (2008) Essential and non-essential elements in the bowhead whale: epidermis-based predictions of blubber, kidney, liver and muscle tissue concentrations. J Cetacean Res Manage 10: 107-117.

35. Tilbury KL, Stein JE, Krone CA, Brownell Jr RL, Blokhin SA, et al. (2002) Chemical contaminants in juvenile gray whales (Eschrichtius robustus) from a subsistence harvest in Arctic feeding grounds. Chemosphere 47: 555-564.

36. Krone CA, Robisch PA, Tilbury KL, Stein JE, Mackey EA, et al. (1999) Elements in liver tissues of bowhead whales (Balaena mysticetus). Mar Mammal Sci 15 123-142.

37. De Luna CJ, Rosales-Hoz L (2004) Heavy metals in tissues of gray whales Eschrichtius robustus and in sediments of Ojo de Liebre Lagoon in Mexico. Bull Environ Contam Toxicol 72: 460-466.

38. Rice DW, Wolman AA, Braham HW (1984) The gray whale, Eschrichtius robustus. Mar Fish Rev 46: 7-13.

39. Agency for Toxic Substances and Disease Registry (ATSDR) (2007) Toxicological profile for barium and barium compounds. ATSDR, Atlanta, GA.

40. McCauley PT, Washington IS (1983) Barium bioavailability as the chloride, sulfate or carbonate salt in the rat. Drug Chem Toxicol 6: 209-217. 